\title{
LETTERS
}

\section{Successful use of infliximab in a patient with treatment resistant spondyloarthropathy related uveitis}

\author{
E Kruithof, P Kestelyn, C Elewaut, D Elewaut, F Van den Bosch, H Mielants, E M Veys, \\ F De Keyser
}

Ann Rheum Dis 2002;61:470

A nterior and intermediate uveitis are inflammatory processes of diverse causes, including among others, infections, trauma, lymphoproliferative disorders, and ischaemia. The remainder are considered to have an immune pathogenesis with an autoimmune component. For example, uveitis is a common manifestation of spondyloarthropathy $(\mathrm{SpA})$, a related group of disorders, with common clinical, biological, genetic, and therapeutic characteristics. ${ }^{1}$ Within the $\mathrm{SpA}$ group of diseases, considerable overlap between the different disease entities can occur-for example, during the course of ankylosing spondylitis, $40 \%$ of the patients will develop acute anterior uveitis (AUU). ${ }^{2}$ In addition, in patients with AUU, SpA is the most commonly identified systemic disease. ${ }^{3}$ Moreover, as is true for other diseases within the SpA group, subclinical gut inflammation has been found in patients with AUU. ${ }^{4}$

From a therapeutic perspective, the management of patients with AAU is targeted at stopping the inflammatory process, in the shortest time possible, as otherwise it might result in irreversible damage leading to impaired visual acuity. Most attacks can be managed by topical steroids and mydriatic agents; in severe episodes of iritis periocular injection of corticosteroids may be beneficial. Occasionally, oral administration of steroids is necessary, sometimes in combination with immunosuppressive agents. However, in some patients the uveitis appears to be treatment resistant; in others, the use of steroids is restricted owing to a lack of response, intolerance, or side effects.

The beneficial effects of tumour necrosis factor $\alpha$ (TNF $\alpha)$ blockade with infliximab (Remicade) are well established in Crohn's disease and, more recently, open and placebo controlled studies indicated a significant improvement of articular symptoms of this treatment in patients with $\mathrm{SpA} .{ }^{6-8}$ Considering the disease overlap within the SpA group and the promising therapeutic results of TNF $\alpha$ blockade in this group of diseases, we suggested that this treatment might possibly provide a clinical benefit in SpA related uveitis. Here, we report the effect of TNF $\alpha$ blockade with infliximab on chronic treatment resistant uveitis in a patient with SpA.

\section{CASE REPORT}

A 45 year old male patient, with pre-existing SpA (fulfilling ESSG criteria), who was HLA-B27 positive, had been known since 1995 to have recurrent anterior uveitis of the left eye, resulting in reactional vitritis, and ultimately evolving into chronic anterior and intermediate uveitis. Topical treatment with steroid drops failed; subconjunctival injections and systemic steroids were repeatedly needed, with only partial improvement. No consistent benefit with sulfasalazine or cyclosporin was seen. As part of an open label pilot programme for $\mathrm{SpA}$, an induction scheme with infliximab (5 $\mathrm{mg} / \mathrm{kg}$ at baseline, week 2 and 6) was started. At baseline visual acuity of the left eye was impaired to 0.63 , with a Tyndall phenomenon ++ . One week after treatment, visual acuity substantially improved to 1.00 , with a Tyndall + to $+/-$.
This improvement was sustained up to week 14-that is, eight weeks after the last infusion, after which a relapse occurred. Retreatment $(5 \mathrm{mg} / \mathrm{kg}$ ) at week 14 was, however, again followed by significant improvement of ocular inflammation and visual acuity. From then on, the patient was re-treated every eight weeks and the ocular inflammation stabilised up to 58 weeks. No subconjunctival injections or systemic steroids were needed during this period, so that steroid administration was substantially reduced.

\section{CONCLUSION}

In view of the beneficial effects of infliximab in Crohn's disease and in $\mathrm{SpA}$, and the observation of clinical benefit in this patient with steroid resistant SpA related uveitis after treatment with infliximab, further exploration of the therapeutic potential of TNF $\alpha$ blockade in SpA related uveitis seems warranted.

\section{Authors' affiliations \\ E Kruithof, D Elewaut, F Van den Bosch, H Mielants, E M Veys, F De Keyser, Department of Rheumatology, Ghent University Hospital, Belgium \\ P Kestelyn, Department of Ophthalmology, Ghent University Hospital C Elewaut, Dendermonde, Belgium}

Correspondence to: Dr E Kruithof, Department of Rheumatology, OK 12IB Ghent University Hospital, De Pintelaan 185, 9000 Gent, Belgium; elli.kruithof@rug.ac.be

Accepted 10 December 2001

\section{REFERENCES}

1 Wright V. Seronegative polyarthritis - a unified concept. Arthritis Rheum 1978;21:618-33

2 Edmunds L, Elswood J, Calin A. New light on uveitis in ankylosing spondylitis. J Rheumatol 1991;18:50-2.

3 Pato E, Banares A, Jover JA, Fernandez-Gutierrez B, Godoy F, Morado $C$, et al. Undiagnosed spondyloarthropathy in patients presenting with anterior uveitis. J Rheumatol 2000;27:2198-202.

4 Banares A, Hernandez-Garcia C, Fernandez-Gutierrez B, Jover JA. Eye involvement in the spondyloarthropathies. Rheum Dis Clin North Am 1998;24:771-84.

5 Mielants H, Veys EM, Verbraeken H, De Vos M, Cuvelier C. HLA-B27 positive idiopathic acute anterior uveitis: a unique manifestation of subclinical gut inflammation. J Rheumatol 1990;17:841-2.

6 Targan SR, Hanauer SB, Van Deventer SJ, Mayer L, Present DH, Braakman T, et al. A short-term study of chimeric monoclonal antibody cA2 to tumor necrosis factor alpha for Crohn's disease. Crohn's Disease cA2 Study Group. N Engl J Med 1997;337:1029-35.

7 Van den Bosch F, Baeten D, Kruithof E, De Keyser F, Mielants H, Veys EM. Treatment of active spondyloarthropathy with infliximab, the chimeric monoclonal antibody to tumour necrosis factor $\alpha$. Ann Rheum Dis 2001;60(suppl III):iii33-6.

8 Brandt J, Alten R, Burmester G, Gromnica-lhle E, Kellner H, Schneider $M$, et al. Three months results of a double-blind placebo-controlled, phase-III clinical trial of infliximab in active ankylosing spondylitis [abstract]. Ann Rheum Dis 2001;60(suppl 1):61 (OP 0063). 


\title{
Incidence of systemic lupus erythematosus among 255 patients with uveitis of unknown origin
}

\author{
J Jiménez-Alonso, M Martín-Armada, M Toribio, M T Herranz-Marín, F Rivera-Cívico, \\ F Pérez-Álvarez
}

Ann Rheum Dis 2002;61:471

the $\mathrm{n}$ reviewing the literature we have noticed a great difference in the prevalence of systemic lupus erythematosus ( SLE) in patients with uveitis. Rosenbaum and Wernick found a prevalence of $0.1 \%,{ }^{1}$ according to the results from several wide American series published in the 1980s. In contrast, Rodríguez et al found a prevalence of $4.8 \%$ in a very heterogeneous population studied retrospectively, and analysed during the same period of time. ${ }^{2}$

We aimed at determining our experience on the incidence of SLE in patients with uveitis by a prospective study carried out during the past decade. Since 1989, the uveitis unit at our hospital has comprised an interdisciplinary team of internists and ophthalmologists carrying out an aetiological protocol study of patients with uveitis of unknown origin..$^{3-5}$ Up to 1999 we had prospectively studied 255 patients with uveitis; none of them had been previously diagnosed with systemic diseases which might have caused uveitis. Three patients met the 1982 revised classification criteria of the American College of Rheumatology for SLE, ${ }^{6}$ representing $1.2 \%$ of our total uveitis cases. Table 1 shows the clinical features and associated pattern of uveitis; cutaneous involvement (malar rash and photosensitivity) was the most common clinical manifestation. Keratoconjunctivitis sicca, which is the most common SLE associated ocular manifestation of the anterior segment of the eye, was present in one patient. On the other hand, none of our patients had retinal vasculitis, and the ocular inflammation responded to topical treatment in all cases.

The prevalence of pathological processes associated with uveitis is variable, and depends on geographical factors, the specialty of the doctor, the hospital where the patients are studied, the retrospective or prospective nature of the study, diagnostic criteria, inclusion of subjects who use drugs by the parenteral route, or HIV infected patients, and inclusion or not of patients with diseases previously known and which cause uveitis. We believe that our results showed accurately the real incidence of SLE among patients with uveitis in our environment: firstly, because we excluded those patients with SLE diagnosed before the ocular inflammation appeared, which might have produced an overestimation of the final number of cases with SLE and, secondly, because of the prospective nature and long follow up of the study.

Thus patient 2 was diagnosed with SLE three years after the first visit because of uveitis. Rodríguez et al considered that SLE was becoming an important cause of anterior uveitis
(3.3\% of total anterior uveitis cases). ${ }^{2}$ This is in accordance with our results because acute anterior uveitis was found to be the ocular pattern in three cases, which represented $2 \%$ of total number of patients with anterior uveitis that we studied. These results were similar to those published by Bañares et al, who found that the cause of anterior uveitis was SLE in 1.8\% of their total cases. ${ }^{7}$ We think that SLE as a cause of uveitis is more common than it has been classically described, and that determination of antinuclear and anti-DNA antibodies should be performed in patients with uveitis with some suggestive clinical signs of lupus.

\section{Authors' affiliations}

J Jiménez-Alonso, M Martín-Armada, F Rivera-Cívico,

F Pérez-Álvarez, Systemic Autoimmune Diseases Unit, Service of Internal Medicine, Granada, Spain

M Toribio, M T Herranz-Marín, Service of Ophthalmology, "Virgen de las Nieves" University Hospital, Granada, Spain

Correspondence to: Dr J Jiménez-Alonso, Jefe del Servicio de Medicina Interna, Hospital Universitario "Virgen de las Nieves", Avda Fuerzas Armadas, 2. 18014-Granada, Spain; jualso@hvn.sas.cica.es

Accepted 25 October 2001

\section{REFERENCES}

1 Rosenbaum JT, Wernick R. The utility of routine screening of patients with uveitis for systemic lupus erythematosus or tuberculosis. A Bayesian analysis. Arch Ophthalmol 1990;108:1291-3.

2 Rodriguez A, Calonge M, Pedroza-Seres M, Akova YA, Messmer EM D'Amico DJ, et al. Referral patterns of uveitis in a tertiary eye care center. Arch Ophthalmol 1996;114:593-9.

3 Herranz Marín MT, Jiménez-Alonso J, Delgado Rodríguez M, Omar $M$, Rivera Civico F, Martin Armada M, et al. Marcadores clinicobiológicos de uveitis secundaria: resultados de un análisis discriminante. Med Clin (Barc) 1997:109.786-91.

4 Rivera-Cívico $F$, Jiménez-Alonso J, Martin-Armada M, Herranz MT, Castro J, Perez-Alvarez F, et al. HLA-B27+ anterior uveitis with or without associated spondyloarthritis: clinical and immunological features. Ann Rheum Dis 1999;58:721-2.

5 Herranz MT, Jiménez-Alonso J, Martín-Armada M, Omar M, Ribera F. Increased prevalence of NIDDM in anterior uveitis. Diabetes Care 1997;20: 1797-8

6 Tan EM, Cohen AS, Fries JF, Masi AT, McShane DJ, Rothfield NF, et al. The 1982 revised criteria for the classification of systemic lupus erythematosus. Arthritis Rheum 1982;25:1271-7.

7 Bañares A, Jover JA, Fernández-Gutiérrez B, Benítez del Castillo JM, García J, Vargas $E$, et al. Patterns of uveitis as a guide in making rheumatologic and immunologic diagnoses. Arthritis Rheum 1997:40:358-70.

\begin{tabular}{lllll} 
Table 1 & \multicolumn{4}{l}{ Clinical characteristics in three women with SLE and uveitis } \\
\hline Case No & $\begin{array}{l}\text { Age (years) at } \\
\text { uveitis flare }\end{array}$ & $\begin{array}{l}\text { Age (years) at } \\
\text { SLE diagnosis }\end{array}$ & $\begin{array}{l}\text { Uveitis } \\
\text { pattern }\end{array}$ & ACR criteria at uveitis presentation \\
\hline 1 & 55 & 55 & AAU, NR & Malar rash, photosensitivity, pericarditis, ANA+ \\
2 & 62 & 65 & AAU, R & $\begin{array}{l}\text { Malar rash, photosensitivity, leucopenia, } \\
\text { lymphopenia, ANA, and anti-dsDNA+ } \\
3\end{array}$ \\
52 & 52 & AAU, NR & $\begin{array}{l}\text { Malar rash, photosensitivity, leucopenia, } \\
\text { lymphopenia, ANA, and anti-dsDNA+ }\end{array}$ \\
\hline
\end{tabular}

AAU, Acute anterior uveitis; NR, non-recurrent; R, recurrent; ANA, antinuclear antibodies; anti-dsDNA anti-double-stranded DNA antibodies. 


\section{Raynaud's phenomenon affecting the tongue of a patient with scleroderma}

\section{J Bridges, C A Kelly}

R aynaud's phenomenon affecting the tongue is a rare but recognised symptom in patients with connective tissue disease, but lack of awareness of its existence by the doctor may lead to a delay in diagnosis. We report a case of Raynaud's phenomenon affecting the tongue in a patient with scleroderma, diagnosed three years after onset of symptoms.

\section{CASE REPORT}

A 61 year old, non-smoking, retired female nurse presented in 1997 with polyarthralgia, fatigue, sclerodactyly, and Raynaud's phenomenon affecting her fingers. Antinuclear antibody and anti-RNP antibody were positive, with anticentromere antibody and anti-Scl-70 antibody negative. A diagnosis of limited cutaneous systemic sclerosis was made according to the classification of LeRoy et al.

She returned a year later complaining of an intermittent, shortlasting, tingling sensation on both sides of the tongue, without obvious precipitating factors. During these episodes, she had difficulty in talking. They did not usually coincide with the occurrence of vasospasm in the digits. She was receiving no drugs known to induce Raynaud's phenomenon. Subsequent magnetic resonance imaging of head and neck was normal, and despite referral to a neurologist, no cause for these symptoms could be found. These symptoms had never occurred during her visits to the clinic, and visual inspection of the tongue had always been normal. She was treated with nifedipine for the Raynaud's disease in her fingers, but she was intolerant of this drug. In December 2000, numbness of the tongue occurred during a routine clinic visit, and a blue-black discolouration of the tongue was noted. Minutes later, the tongue had returned to its normal red appearance, and the patient was again asymptomatic. A diagnosis of Raynaud's phenomenon of the tongue was made, and treatment was started with Losartan. This led to a moderate improvement in her symptoms.

\section{DISCUSSION}

Raynaud's disease of the tongue may occur in patients with connective tissue disease, ${ }^{23}$ or in patients without underlying disease. ${ }^{4}$ Symptoms include dysarthria, temporary paraesthesia, lingual ulceration, and tongue spasms, and diagnosis rests on careful history taking and, ideally, confirmation of colour change of the tongue during an acute attack. The intermittent, shortlasting nature of the symptoms may cause diagnostic difficulty, as the tongue is normal in between attacks. Treatment is similar to that of Raynaud's disease of the digits, and successful outcomes have been reported with nifedipine. ${ }^{3}$ Success has also been reported with prednisolone in cases of Raynaud's phenomenon of the tongue associated with systemic lupus erythematosus. ${ }^{2}$

This case of Raynaud's disease of the tongue highlights the need to assess thoroughly any patient with connective tissue disease who presents with atypical oral symptoms, and to inspect the tongue carefully during the presence of symptoms.

\section{Authors' affiliations}

M J Bridges, C A Kelly, Rheumatology Department, Queen Elizabeth Hospital, Sheriff Hill, Gateshead, Tyne and Wear NE9 6SX, UK

Correspondence to: Dr Bridges

Accepted 26 October 2001

\section{REFERENCES}

1 LeRoy EC, Black C, Fleischmajer R, Jablonska S, Kreig T, Medsger TA, et al. Scleroderma (systemic sclerosis): classification, subsets and pathogenesis. J Rheumatol 1988;15:202-5.

2 Da Cunha Bang F, Lange Wantzin G, Dahl Christensen J. Raynaud's phenomenon with oral manifestations in systemic lupus erythematosus. Dermatologica 1985;170:263-4

3 Nielsen H V, Kristensen J K, Klemp P, Staberg B, Thomsen K. Paroxysmal dysarthria and Raynaud's phenomenon in the tongue. Acta Med Scand 1984:216:431-2.

4 Giunta J L. Raynaud's disease with oral manifestations. Archiv Dermatol $1975 ; 111: 78-80$ 


\title{
T cell response to human HSP60 and yersinia $19 \mathrm{kDa}$ in ankylosing spondylitis and rheumatoid arthritis: no evidence for a causal role of these antigens in the pathogenesis
}

\author{
J Zou, M Rudwaleit, A Thiel, R Lauster, J Braun, J Sieper
}

Ann Rheum Dis 2002;61:473-474

$\mathrm{T}$ he pathogenesis of two important inflammatory rheumatic diseases, rheumatoid arthritis (RA) and ankylosing spondylitis (AS), is not clear. In both diseases an immune response against an unknown autoantigen may have a crucial role. $^{12}$ It has been repeatedly suggested that heat shock proteins (HSP) play a part in various autoimmune diseases such as RA, diabetes, and multiple sclerosis, ${ }^{3}$ based on high interspecies sequence homologies, inducible tissue expression, and a strong immunogenicity. On the other hand, some studies indicate that HSP may even be protective in arthritis. ${ }^{4}$

The $19 \mathrm{kDa}$ urease $\beta$ subunit of yersinia is regarded as a major immunodominant protein for both $\mathrm{T}$ cell and antibody responses in patients with yersinia induced reactive arthritis. ${ }^{5}$ Because $20-30 \%$ of HLA-B27+ patients with yersinia induced reactive arthritis develop the full picture of AS after 10-20 years, ${ }^{6}$ it is an obvious question to ask whether a $\mathrm{T}$ cell response against the yersinia-specific $19 \mathrm{kDa}$ protein is also detectable in patients with AS. Until now, there has been insufficient evidence to support a relationship between yersinia infection and RA.

\section{PATIENTS AND METHODS}

In this study 45 patients with active AS and 22 with active RA were recruited from the outpatient clinic of the University Hospital Benjamin Franklin, Berlin. In vitro stimulation of CD4 + T cells by protein antigen was carried out for six hours, as described previously. ${ }^{78}$ Brefeldin A ( $10 \mu \mathrm{g} / \mathrm{ml}$; Sigma) was

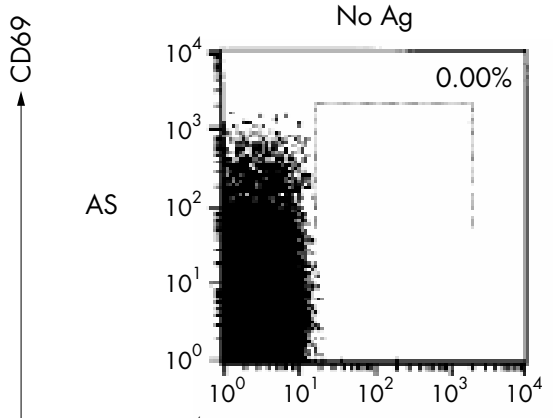

RA
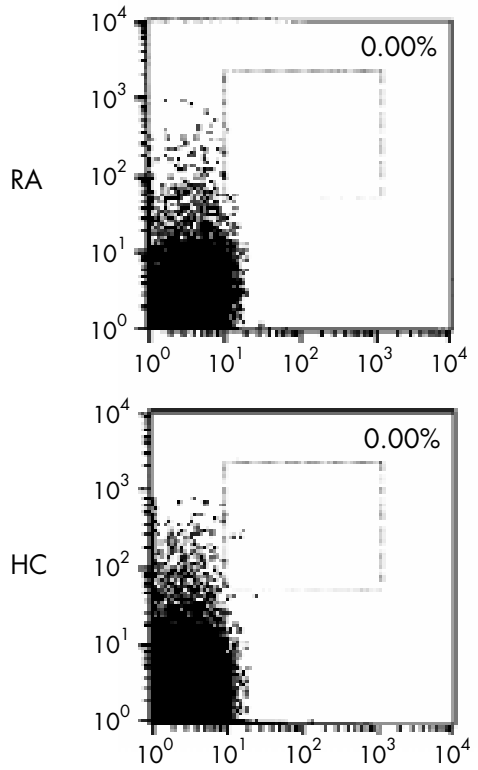

h-HSP60
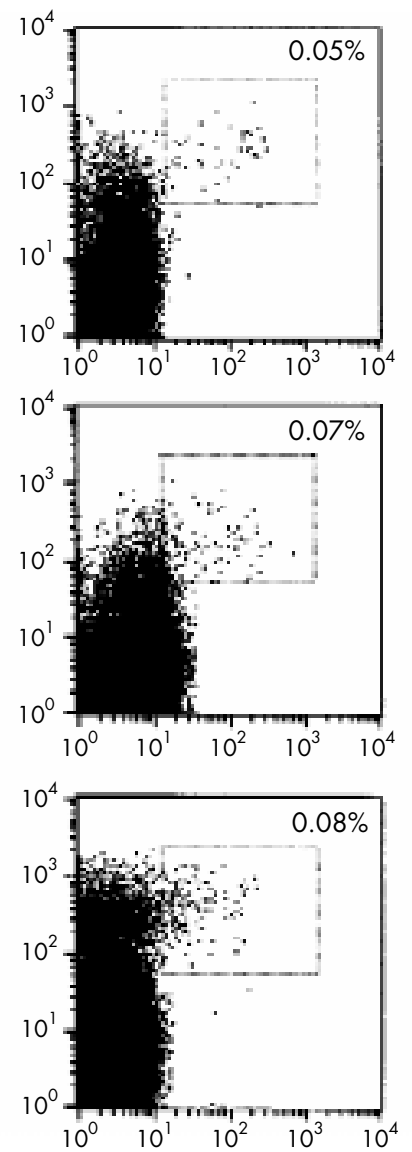

Y-19 kDa
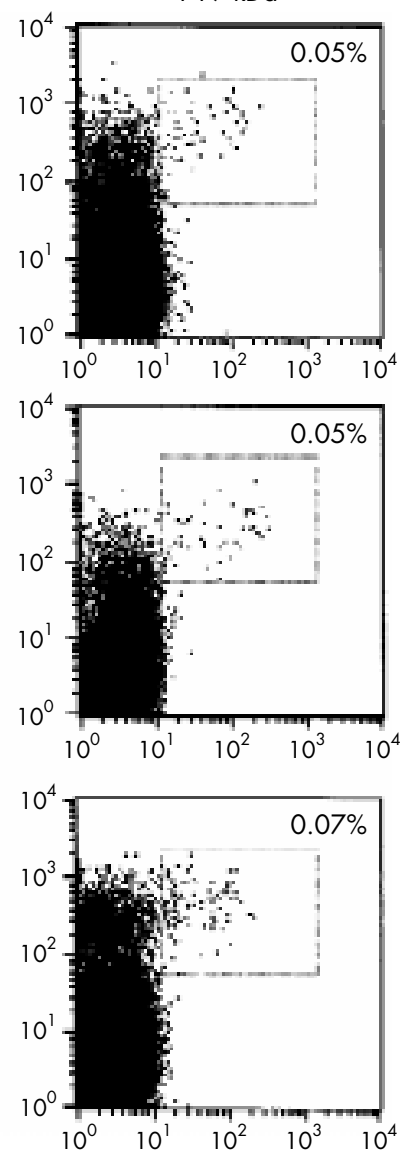

IFN $\gamma$

Figure 1 Examples of the antigen-specific response to the human (h)-HSP60 or yersinia (Y)-19 kDa compared with stimulation without antigen, in a patient with ankylosing spondylitis (AS) or rheumatoid arthritis (RA) or a healthy control (HC). After staining for T cell surface markers and intracellular cytokines a gate for CD4+ T cells was set. The percentage of IFN $\gamma / C D 69$ double positive cells of the CD4+ T cell subpopulation is indicated. 


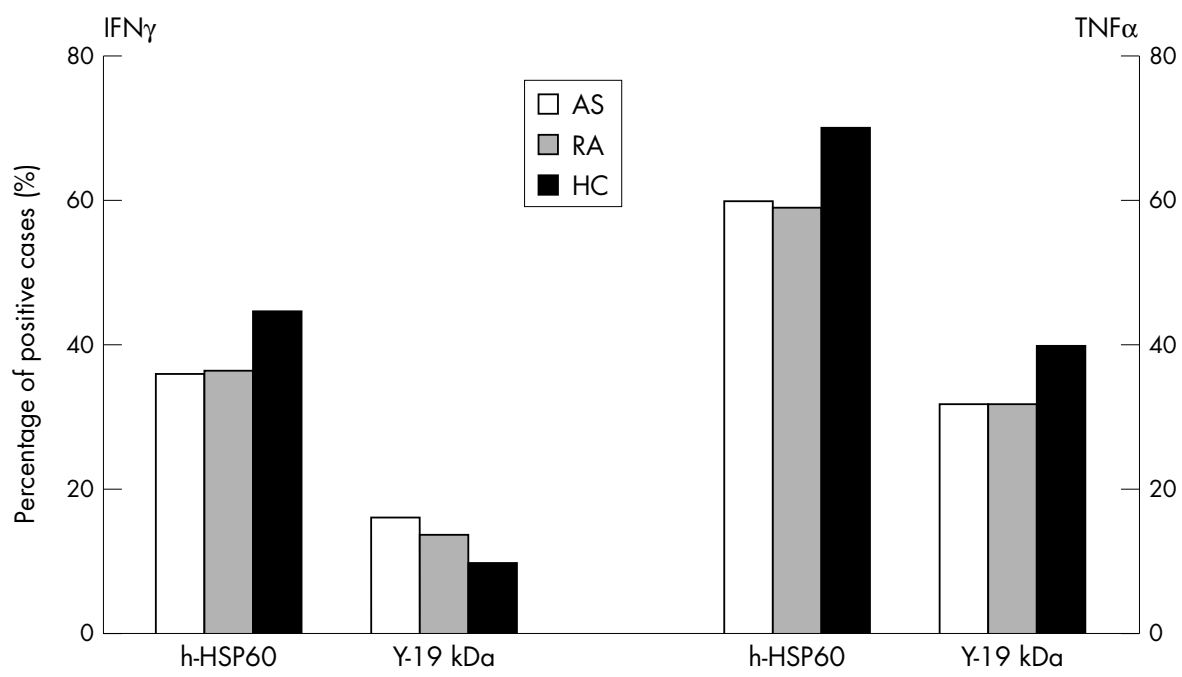

Figure 2 Percentage of patients with ankylosing spondylitis (AS, n=45), with rheumatoid arthritis (RA, $n=22$ ), and of healthy controls (HC, $\mathrm{n}=20$ ) responding to in vitro stimulation with the human heat shock protein 60 (h-HSP60) or yersinia $19 \mathrm{kDa}$ (Y-19 kDa). Response was measured either by IFN $\gamma$ or TNF $\alpha$ production of CD4+ T cells after antigen-specific stimulation in comparison with stimulation without antigen.

The analysis was made with whole peripheral blood.

added for the last four hours of the stimulation for accumulation of intracellular cytokine. After fixation with $2 \%$ formaldehyde, the cells were quadruply stained for CD4, CD69 surface marker, and for the intracellular cytokines interferon $\gamma($ IFN $\gamma)$ and tumour necrosis factor $\alpha(\mathrm{TNF} \alpha) .{ }^{78}$ After gating on CD4+ $\mathrm{T}$ cells, only cytokine positive $\mathrm{T}$ cells which were also positive for the early activation antigen CD69 were counted.

\section{RESULTS}

After stimulation with staphylococcal enterotoxin B the percentage of positive cells was always $>8 \%$, whereas after stimulation with no antigen the percentage was always $<0.01 \%$. Samples with more than $0.05 \%$ CD69/cytokine double positive cells out of the $\mathrm{CD} 4+\mathrm{T}$ cell population were regarded as positive. ${ }^{78}$ Figure 1 shows examples of $\mathrm{T}$ cell responses to human (h)-HSP60 and Y-19 kDa in one patient with AS, one with RA and a healthy control (HC).

There was no difference between the patients with AS, those with RA, and healthy controls (fig 2) in the peripheral blood $\mathrm{T}$ cell response to the h-HSP60 as judged by the percentage of CD69/IFN $\gamma$ or CD69/TNF $\alpha$ double positive CD4+ T cells.

For synovial fluid (SF), 5/7 (71\%) patients with AS and 3/4 (75\%) patients with RA showed a T cell response to h-HSP60 by IFN $\gamma$ secretion. Six of seven (86\%) patients with AS and 3/4 (75\%) with RA showed a TNF $\alpha$ secretion in response to h-HSP60. In comparison with peripheral blood, the h-HSP60specific IFN $\gamma / \mathrm{TNF} \alpha$ responses were stronger in SF (mean (SD) $0.18(0.3)$ in SF $v 0.09$ (0.08) in peripheral blood for IFN $\gamma ; 0.35$ $(0.64)$ in SF $v 0.15(0.05)$ in peripheral blood for TNF $\alpha)$, but this difference was not significant $(p>0.05$ for both cytokines).

As judged by the percentage of CD69/IFN $\gamma$ double positive $\mathrm{CD} 4+\mathrm{T}$ cells, a similar T cell response to the Y-19 kDa was also found in peripheral blood in all three groups (fig 2). Although a higher percentage of patients with AS (3/7 (43\%) patients for IFN $\gamma ; 5 / 7(71 \%)$ patients for TNF $\alpha)$ than with RA (1/4 (25\%) patients for IFN $\gamma ; 2 / 4$ (50\%) patients for TNF $\alpha$ ) showed a synovial $\mathrm{T}$ cell response to the $19 \mathrm{kDa}$ protein; this difference was non-significant, possibly owing to the small number of patients.

\section{DISCUSSION}

These results suggest that T cell responses to h-HSP60 and to Y-19 kDa are present in all three groups and seem therefore not to be pathogenic. We cannot exclude the possibility that $\mathrm{T}$ cells specific for one of the two antigens are present in synovium and just are not detected in peripheral blood. However, the absence of clear differences between antigen-specific $\mathrm{T}$ cells in the SF of patients with RA and AS argues against this, unless a similar pathogenesis for these two diseases is assumed, which is unlikely.

\section{Authors' affiliations}

J Zou, M Rudwaleit, J Braun, J Sieper, Department of Rheumatology, Klinikum Benjamin Franklin, Free University, Berlin, Germany A Thiel, R Lauster, J Sieper, German Rheumatology Research Centre, Berlin, Germany

J Braun, Rheumzentrum Herne, Germany

Correspondence to: Professor J Sieper, Medical Department I, Rheumatology, University Hospital Benjamin Franklin, Hindenburgdamm 30, 12200 Berlin, Germany; hjsieper@zedat.fu-berlin.de

Accepted 10 December 2001

\section{REFERENCES}

1 Sieper J, Braun J. Pathogenesis of spondylarthropathies. Persistent bacterial antigen, autoimmunity, or both? Arthritis Rheum 1995;38:1547-54.

2 Choy EH, Panayi GS. Cytokine pathways and joint inflammation in rheumatoid arthritis. N Engl J Med 2001;344:907-16.

3 Auger I, Escola JM, Gorvel JP, Roudier J. HLA-DR4 and HLA-DR 10 motifs that carry susceptibility to rheumatoid arthritis bind 70-kD heat shock proteins. Nat Med 1996;2:306-10.

4 Van der Zee R, Anderton SM, Prakken AB, Liesbeth Paul AG, Van Eden $W$. T cell responses to conserved bacterial heat-shock-protein epitopes induce resistance in experimental autoimmunity. Semin Immunol 1998;10:35-41.

5 Mertz AK, Ugrinovic S, Lauster R, Wu P, Grolms M, Bottcher U, et al. Characterization of the synovial T cell response to various recombinan yersinia antigens in Yersinia enterocolitica-triggered reactive arthritis. Heat-shock protein 60 drives a major immune response. Arthritis Rheum 1998;41:315-26

6 Leirisalo-Repo M. Prognosis, course of disease, and treatment of the spondyloarthropathies. Rheum Dis Clin North Am 1998;24:737-51.

7 Thiel A, Wu P, Lauster R, Braun J, Radbruch A, Sieper J. Analysis of the antigen-specific $T$ cell response in reactive arthritis by flow cytometry. Arthritis Rheum 2000;43:2834-42.

8 Kuon W, Holzhutter HG, Appel H, Grolms M, Kollnberger S, Traeder A, et al. Identification of HLA-B27-restricted peptides from the Chlamydia trachomatis proteome with possible relevance to HLA-B27-associated diseases. J Immunol 2001;167:4738-46. 


\section{Kikuchi-Fujimoto disease and peripheral arthritis: a first!}

\section{E Graham}

$\mathrm{K}$ ikuchi-Fujimoto disease is a subacute necrotising lymphadenopathy of unknown cause. It is more common in young Asian women, usually affects cervical lymph nodes, and is characterised histologically by histiocytic proliferation and necrosis of lymph nodes. Clinically the lymphadenopathy is painless, there is an associated high grade fever, sore throat, and erythematous skin rash. ${ }^{12}$ The course is usually benign with resolution in a few months with the use of non-steroidal anti-inflammatory drugs. This condition was first described independently by Kikuchi and Fujimoto in 1972. ${ }^{34}$ As far as I know, the association of Kikuchi-Fujimoto disease with small and large joint polyarthritis has not been described before.

\section{CASE REPORT}

A 22 year old woman from western Nepal presented with a high grade fever, severe generalised joint pains, sore throat, and rashes for five weeks. On examination she looked ill and had a temperature of $105^{\circ} \mathrm{C}$. She had painless cervical and inguinal lymphadenopathy, significant synovitis of symmetrical large and small joints, including distal and proximal interphalangeal joints, and a circumscribed erythematous scaling rash on chest, back, hairline, and legs. No organomegaly was present. Respiratory and cardiovascular examination were normal.

Investigations showed a daily spiking temperature of $105^{\circ} \mathrm{C}$, erythrocyte sedimentation rate $125 \mathrm{~mm} / \mathrm{lst} \mathrm{h}$, packed cell volume 0.28 , raised white cell count $13.3 \times 10^{9} / 1$, aspartate aminotransferase $283 \mathrm{U} / \mathrm{l}($ normal $<34)$, and alanine aminotransferase $374 \mathrm{U} / \mathrm{l}$ (normal <31). Creatinine and urine analysis were normal; urine and blood culture were negative; antinuclear antibody, rheumatoid factor, and hepatitis B surface antigen were all negative. A chest $x$ ray examination was normal. A hand $x$ ray examination showed periarticular osteoporosis. Lymph node biopsy disclosed histiocytic necrotising lymphadenitis. A diagnosis of Kikuchi-Fujimoto disease was made. She did not respond to two weeks' treatment with high dose aspirin and two weeks' treatment with maximum dose indometacin. A reducing course of prednisolone $40 \mathrm{mg}$ was given over eight weeks, which resulted in a complete recovery.

\section{DISCUSSION}

This case is important for three reasons. Firstly, young Asian women presenting with symptoms and signs in keeping with a diagnosis of acute systemic lupus erythematosus, tuberculosis, or even adult Still's disease should have a lymph node biopsy in order to rule out the more benign condition of Kikuchi-Fujimoto disease. Secondly, Kikuchi-Fujimoto disease has been described in association with encephalitis, neuritis, and arthralgia. This is the first description of an association with extensive small and large joint synovitis. Thirdly, most patients with Kikuchi-Fujimoto disease respond well to non-steroidal anti-inflammatory drugs. This patient required a reducing dose of steroids over eight weeks in order to treat the synovitis. When this condition occurs in association with synovitis, steroids may be needed.

\section{Author's affiliation}

L E Graham, Department of Medicine, Patan Hospital, Kathmandu, Nepal

Correspondence to: Dr L Graham, Patan Hospital, GPO Box 252, Kathmandu, Nepal; lorradam@wlink.com.np

Accepted 6 November 2001

\section{REFERENCES}

1 Turner RR, Martin J, Dorfman RF. Necrotizing lymphadenitis. A study of 30 cases. Am J Surg Pathol 1983;7:1 15-23.

2 Dorfman RF. Histiocytic necrotizing lymphadenitis of Kikuchi and Fujimoto. Arch Pathol Lab Med 1987; 1 11:1026-9.

3 Kikuchi M. Lymphadenitis showing focal reticulum cell hyperplasia and nuclear debris and phagocytosis. Nippon Ketsueki Gakkai Zasshi 1972;35:379-80.

4 Fujimoto Y, Kozima Y, Yamaguchi K. Cervical sub-acute necrotizing lymphadenitis. A new clinicopathologial entity. Naika 1972;20:920-7. 